This item was submitted to Loughborough's Research Repository by the author.

Items in Figshare are protected by copyright, with all rights reserved, unless otherwise indicated.

\title{
Encouraging the commercial sector to help employees to change their travel
} behaviour

PLEASE CITE THE PUBLISHED VERSION

PUBLISHER

(c) Elsevier

LICENCE

CC BY-NC-ND 4.0

REPOSITORY RECORD

Enoch, Marcus P., and Stephen Potter. 2019. "Encouraging the Commercial Sector to Help Employees to Change Their Travel Behaviour". figshare. https://hdl.handle.net/2134/3333. 
This item was submitted to Loughborough's Institutional Repository by the author and is made available under the following Creative Commons Licence conditions.

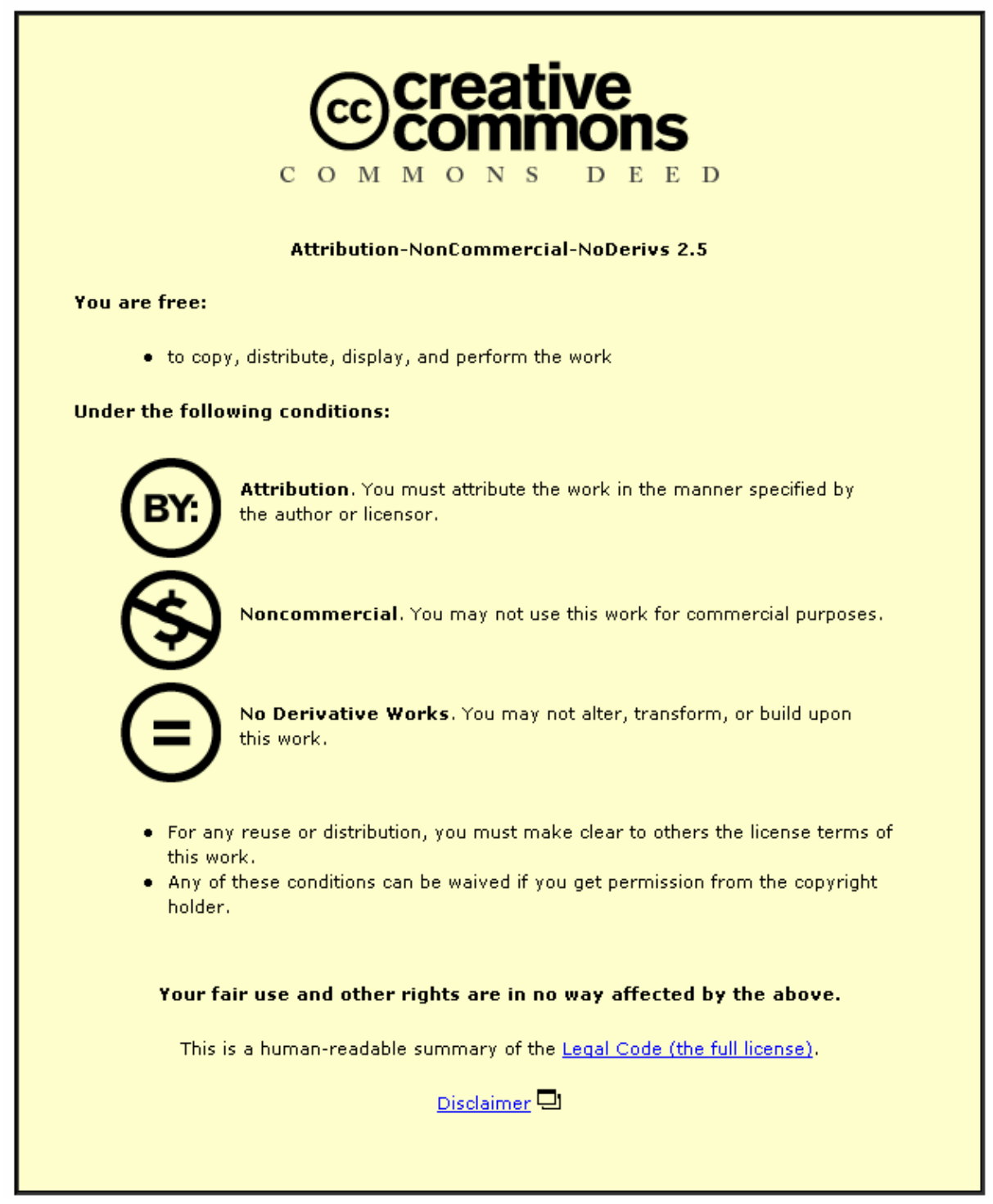

For the full text of this licence, please go to: http://creativecommons.org/licenses/by-nc-nd/2.5/ 


\title{
Encouraging the Commercial Sector to help Employees to change their Travel Behaviour
}

\author{
Dr. Marcus Enoch and Dr. Stephen Potter, \\ Centre for Technology Strategy, \\ The Open University, \\ Walton Hall, \\ Milton Keynes, \\ MK7 6AA
}

Tel: 01908653970

Email m.p.enoch@open.ac.uk; s.potter@open.ac.uk

\section{Introduction}

In July 1998, the Government's White Paper on transport policy was published (Department of the Environment, Transport and the Regions, 1998), with the intention to reduce transport dependence on the private car. One element of this was the need for the "widespread voluntary take-up" of Green Transport Plans (now called Travel Plans), while one of the six key purposes of the new Local Transport Plans is to "promote green transport plans for journeys to work, school and other places". Thus the development of Travel Plans represents one of several policy mechanisms in the crucial area of managing travel demand.

However, although its own departments and other parts of the state sector have now adopted Travel Plans, any policy mechanisms to encourage the "widespread voluntary take-up" in the private sector have been relatively low key.

The purpose of this paper is to explore how commercial sector organisations are currently encouraged to help change their employees travel behaviour, and at how this process could be improved in the future.

\section{Incentive Mechanisms for Employers}

Bluntly, there are effectively four mechanisms to persuade the commercial sector to encourage their staff to commute in a 'greener' way: through

1. Information and exhortation

2. Regulation

3. Subsidies; and the 


\section{Fiscal system}

\section{Information and Exhortation}

Unsurprisingly, thus far the main emphasis to commercial organisations to encourage them to help employees to change travel behaviour has been on information provision - as detailed in the White Paper - with its commitment to expanding the voluntary take up of Travel Plans. This has been backed up by publicity campaigns emphasising the need for all to contribute to solving the transport crisis.

The effort made in this area has been extensive. Transport 2000 has been commissioned by the Department of Transport, Local Government and the Regions to update its best-practice guide. Past examples of literature produced include: Travel Plan Resource Pack for Employers; and Preparing your organisation for transport in the future: the benefits of green transport plans: The Guide (see http://www.dtlr.gov.uk). An important element in the information approach is the idea that Travel Plans are not all cost, but that they actually produce benefits to the organisation. The concept is one of educating commercial organisations to recognise this exists and how to capture the financial (and many other) benefits.

While there is no doubt that this information performs a useful function, in practice this approach is making very little headway. Employers have usually perceived that Travel Plans are about 'sharing the pain'. It is not surprising therefore, that the main reaction from industry and commerce has been pain avoidance!

The benefits message is not getting through and the plain fact is that companies tend only to listen when some other pressing reason forces them to address the issue of how they get their staff to work (Rye, 2002). In some cases this may be congestion or a lack of parking spaces, but in most cases this pressing reason is the local authority forcing them to look at alternative ways of transporting their employees through a Section 106 planning agreement, i.e. regulation!

\section{Regulation}

Regulation through planning agreements theoretically works by aiming to ensure that new developments over a certain size develop a Travel Plan that works to reduce the proportion of trips made by a single occupant car from the day those developments open. In England and Wales, national guidance on how this should be applied has been laid down in the last two editions of Planning Policy Guidance Notes 13 (PPG 13) - on transport and land use. This guidance has attached significant importance to Travel Plans, and advises that local authorities should include Travel Plans as a part of their own planing policy (through the Local Plan document), and should also require all large scale employment, retail and leisure developments to have a Travel Plan (Rye, 2002).

However, there are problems with the approach. In the UK, regulation is limited only to where employers require planning permission to develop a new or existing site. This means that more often than not it is suburban and city-edge sites that are required to implement Travel Plans, not necessarily the companies in areas of greatest need. In addition, there are several other problems as far as using 
planning agreements to limit traffic growth. One is that the planning rules are implemented purely at discretion of local authorities, and although PPG 13 is now increasingly encouraging more standardisation in how these are applied, Institution of Highways and Transportation (1997) notes:

'As with many other demand management measures, competition between adjacent localities for economic strength can seriously reduce the effectiveness of well-intended policies. Given the choice between accommodating the requirements of a major project, which will enhance the local economy, by relaxing their more stringent policies or maintaining those policies and seeing the project go elsewhere, many authorities will opt for the former. While a firm national, or regional, policy framework might help to avoid such 'bidding' situations, it would be at some cost to local autonomy on key decisions.'

IHT (1997), pp.293

At the practical/detail level too, there are difficulties mainly due to Travel Plans being a relatively new practice. For example, there is very little data on how effective Travel Plans are - making it difficult for local authorities to judge whether a Travel Plan is good enough or not. In addition, developers do not often know how to write Travel Plans, leading to negotiations and delay while the Plan is improved. Finally, many development proposals are speculative and transport is dealt with at the outline planning stage. This means that often there is not a very high level of detail about the type of development, number of employees etc., which adds to the difficulty of drawing up the Travel Plan (Rye, 2002).

In other countries, a whole regulatory framework governs how companies deal with how they get their employees to work. The following section draws extensively on the Transportation Demand Management encyclopaedia of the Victoria Transport Policy Institute (Litman, 2001).

In the USA, some State/Provincial, regional and local jurisdictions mandate so-called Commute Trip Reduction (CTR) programs for certain types of employers. For ease of administration, mandatory CTR laws often apply only to large employers (those with at least 50 or 100 per employment site), although this limits their effectiveness since the majority of employees in most areas work for smaller companies. However, at least this measure is not simply restricted to when development occurs. Smaller employers can form a Transportation Management Association to provide CTR services in a particular location. Many transportation planning and transit agencies provide support for CTR programs, and developers may implement CTR programs in exchange for reduced parking requirements.

According to Comsis (1993) and Winters and Rudge (1995), a comprehensive CTR program can reduce peak-period automobile trips by $10-30 \%$ at a work location. Impacts vary depending on program design, geography and employee demographics.

One example of an effective CTR program was introduced by the State of Washington in 1991 under its Clean Air Act. Subsequently revised in 1997, this law requires employers with more than 100 employees at a worksite who begin work between 6 and 9a.m. in counties with more than 150,000 population to establish programs intended to reduce peak-period trips 20\% by 1997 (compared with 1991), 25\% by 1999 and 35\% by 2005. In Washington State the law requires certain planning and 
monitoring activities but imposes no punishment if employers fail to meet the planning objectives. In other areas some regulations include penalties if commercial developers fail to meet agreed maximum SOV mode split targets, e.g. the City of Cambridge, Massachusetts. Developers pass these requirements on to facility users through lease agreements and tenant fees, resulting in the implementation of Commute Trip Reduction programs (Litman, 2001).

Another approach is used in Santa Monica, California, where the local council has introduced a mandatory Parking Cash Out program (United States Environmental Protection Agency, 2000). This applies to firms employing 50 or more people that have at least one work site located in the South Coast Air Basin who:

- do not own their own parking (normally this means parking is leased),

- $\quad$ subsidise employee parking (i.e., pay all or part of the cost of parking for any employee)

- can calculate the out-of-pocket amount paid for subsidised employee parking (e.g., parking costs are unbundled, or separated in the lease agreement), and

- can reduce the number of parking spaces leased without penalty (e.g., without having to break the lease or pay for unused spaces).

Such employers are required to offer all eligible employees the option - in lieu of subsidised parking of a cash allowance equivalent to the parking subsidy. Eligible employees are those to whom a subsidised parking space is available, even if it is not used. The parking subsidy is equal to the out-ofpocket amount paid by the employer for employee parking minus any contribution by the employee and minus any commute-related subsidies otherwise given to the employee (e.g., for mass transit or ridesharing). Employees have the choice of foregoing the cash offer and continuing to receive subsidised parking or accepting the offer and either paying for parking themselves or finding an alternative way to commute to work. Santa Monica recognises Parking Cash Out for its contribution to overall trip reduction and to the emissions reduction requirements of the areas Clean Air laws.

There are parallels to the regulatory approach of the USA elsewhere. In the Paris region, employers have been required to refund half the cost of the Carte Oranges, or season ticket (Flowerdew, 1993) since 1983. Transport legislation enacted in 1982 provides that all the employers of the Paris area have as an obligation to refund with paid part of the expenditure of public transport to go of their residence to their place of work. The assumption of responsibility of these expenses is fixed at $50 \%$ of the price of a 2nd class fare. This refunding relates exclusively to public transport and must be discharged by the employer as soon as possible, i.e. at the latest at the end of the month following that of their use. Firms with fewer than six employees are exempt from the employer's contribution to the cost of the travelcard.

Brazilian employers are required to subsidise some workers' transportation costs under the 'Vale Transporte'. Any amount spent on transportation above $6 \%$ of income, up to a $20 \%$ maximum, is subsidised by employers. Employers purchase bus tokens and distribute them to eligible employees with their pay packets (TCRP, 1996). Although this allows realistic fares to be set without over 
penalising the poor, there is evidence that this has led to a parallel currency and incentivised informal public transport provision (Santos-Pereira and Alouche, 1999).

The Italian Government too, has begun pursuing a more mandatory approach to Travel Plans. In 1998, the Italian Environment Ministry mandated the Decree on Sustainable Mobility in Urban Areas. Employers of over 300 staff or 800 freelancers must designate a mobility manager who must coordinate efforts of employees in reducing systematic home work trips through a site specific mobility plan. But, no quantitative targets are set and no penalties are in place for companies not complying (MOST, 2001).

Overall, the UK approach to regulating for the use of Travel Plans as a requirement of new development stands in contrast with the USA style experience of requiring travel plans from virtually all employers in places where congestion and traffic pollution are a major problem. However in all situations regulation tends to generate a view that Travel Plans are a cost - and not a benefit to be exploited, providing a contradictory message to the information and exhortation approach and leading to a counterproductive attitude. Indeed in the USA, this 'counterproductive attitude' led to the Federal Clean Air legislation that had imposed mandatory travel plans on companies of over 100 employees in major urban areas being repealed in 1996 after lobbying from businesses (Rye, 2002). And in Belgium, the strongly negative reaction of businesses to compulsory commuting plans for businesses larger than 50 employees in 1999, meant the proposals were dropped (Van der Hallen, 1999). Instead, from 1st January 2003, companies of more than 100 employees will be expected to produce a diagnosis of the travel problems faced by their workers every three years. This will detail working hours, worker locations, modes currently used, the access profile of companies and employer measures already taken to improve transport access, and will be integrated with other government administration like social services and will be completed electronically. The process will begin in June 2003 (Gailly, 2002).

Finally, the problem of 'greenwash', whereby developers produce an impressive list of 'environmentally friendly' proposals but fail to implement them either effectively or at all, has led the UK Government to develop an evaluation system to 'police' regulations.

This movement to a more regulatory structure is actually a shift in the opposite direction to the experience in the USA. There the regulatory approach is now seen as less important than before, with Federal regulations in the sector having being dropped. Instead, these limitations of using regulatory mechanisms to influence policy have been widely recognised in recent years, and have led to other types of instrument - notably fiscal - to be developed. If incentives are offered to both commercial organisations and their employees then the benefits to them both of greening travel become abundantly clear.

\section{Subsidies}

One way by which fiscal incentives could be introduced is through a public subsidy. As yet, when it comes to encouraging employers to introduce Travel Plans in Britain it could be argued that subsidies have been used in two small ways. One was through the grant from the Department of Transport, Local Government and the Regions of bursaries to pay for 111 Travel Co-ordinators in some local authorities, 
and the second has been a project to provide expert consultations for some companies embarking on the process. Essentially though, both examples were on a limited scale, and could be seen more as an add-on to the information approach rather than a subsidy policy as such.

A similar scheme has operated in the USA, where The Space Coast Area Transit Agency in Southern Florida supports the Space Coast Commuter Assistance (SCCA) program to help commuters use alternative modes. The agency helps develop individualised commute trips reduction programs for each business, and makes no charge for SCCA's services (Litman, 2001). And in Linz, Austria, the City Council offers a free mobility consulting service to the 450 companies with 50 employees or more (Schippani, 2002).

One area where direct cash subsidies have been used is in Montreal, Canada, where a fund of $\$ C 3.18 \mathrm{~m}^{1}(€ 2.22 \mathrm{~m})$ is being used to offer employers of more than 50 workers financial help to develop TDM plans (Coulliard, 2002). And in Italy, the Environment Ministry has set aside $€ 15.5 \mathrm{~m}$ over three years to finance up to $50 \%$ of the company mobility plans design and implementation costs (MOST, 2001).

Another form of subsidy occurs where public transport bodies (sometimes in partnership with the local authority) offer employers discounts for buying public transport passes in bulk. The Ecopass in Ottawa, Canada is one such scheme that is currently being piloted. Member companies gain a $15 \%$ discount on annual passes that are paid for through payroll deduction (OC Transpo, 2001). In Seattle, the King County METRO Transit Agency provides travel passes at a discount to employers to encourage staff to commute by a variety of modes other than the car, as one element of a commute trip reduction program. Interestingly, employers joining the scheme for the first time may also be eligible for match funding through Federal transport grants (Litman, 2001; King County Metro, 1999; King County Metro, 2000).

In Britain, the energy policy sector has used subsidies to encourage more environmentally sensitive behaviour for a number of years. For example, the Energy Savings Trust has used subsidy to 'kick start' the market for a number of energy saving technologies such as compact fluorescent lightbulbs and condensing gas boilers. The idea was to get the market developed to a point where the subsidies could be removed. In 1996 this approach was adopted for clean fuel vehicles with the launch of the TransportAction PowerShift programme.

\footnotetext{
${ }^{1}$ Where $\$ C 1=€ 0.70(\mathrm{XE}, 2002)$.
} 


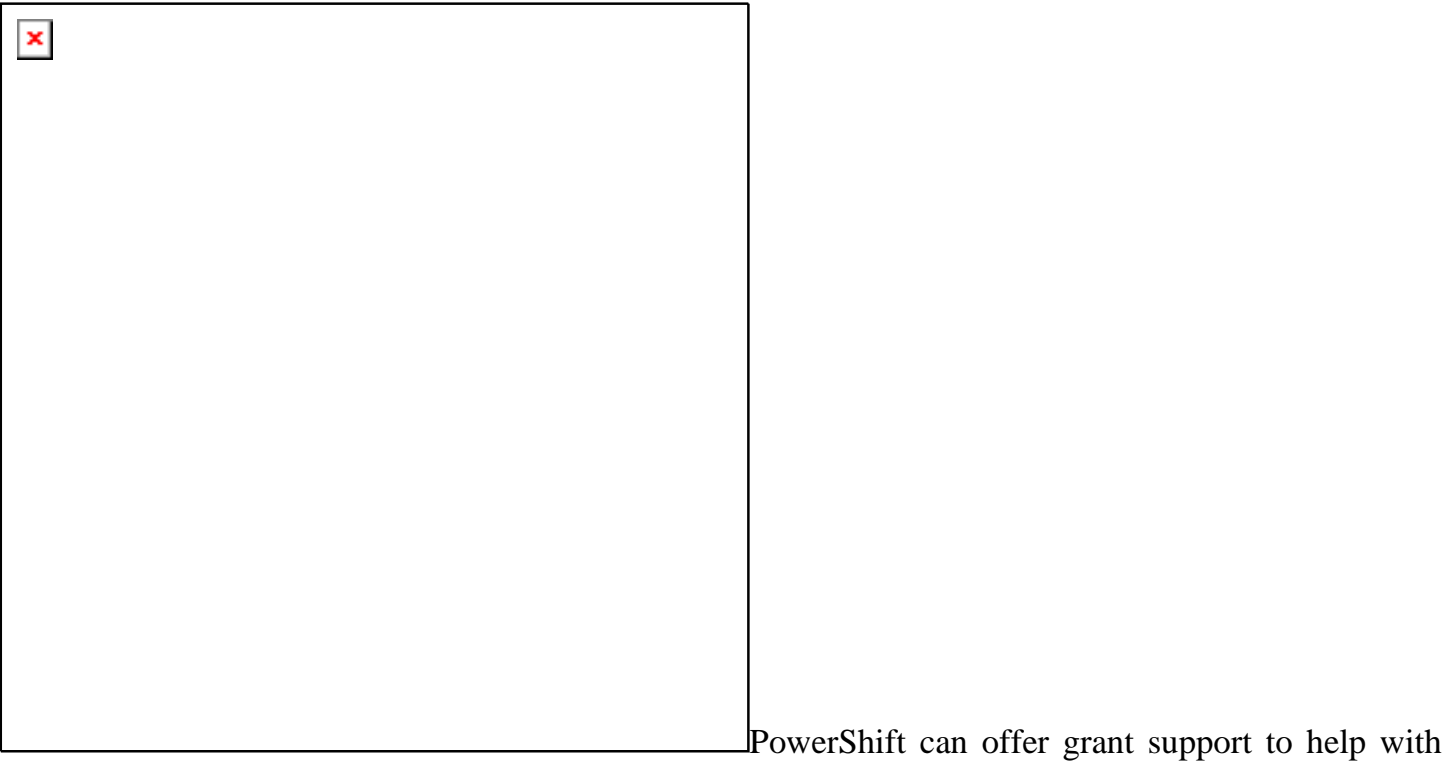
the purchase of vehicles which are proven to offer emissions benefits and which have been shown to be technically viable. These include vehicles running on compressed natural gas (CNG), liquified natural gas (LNG), liquefied petroleum gas (LPG) and electricity (including hybrids).

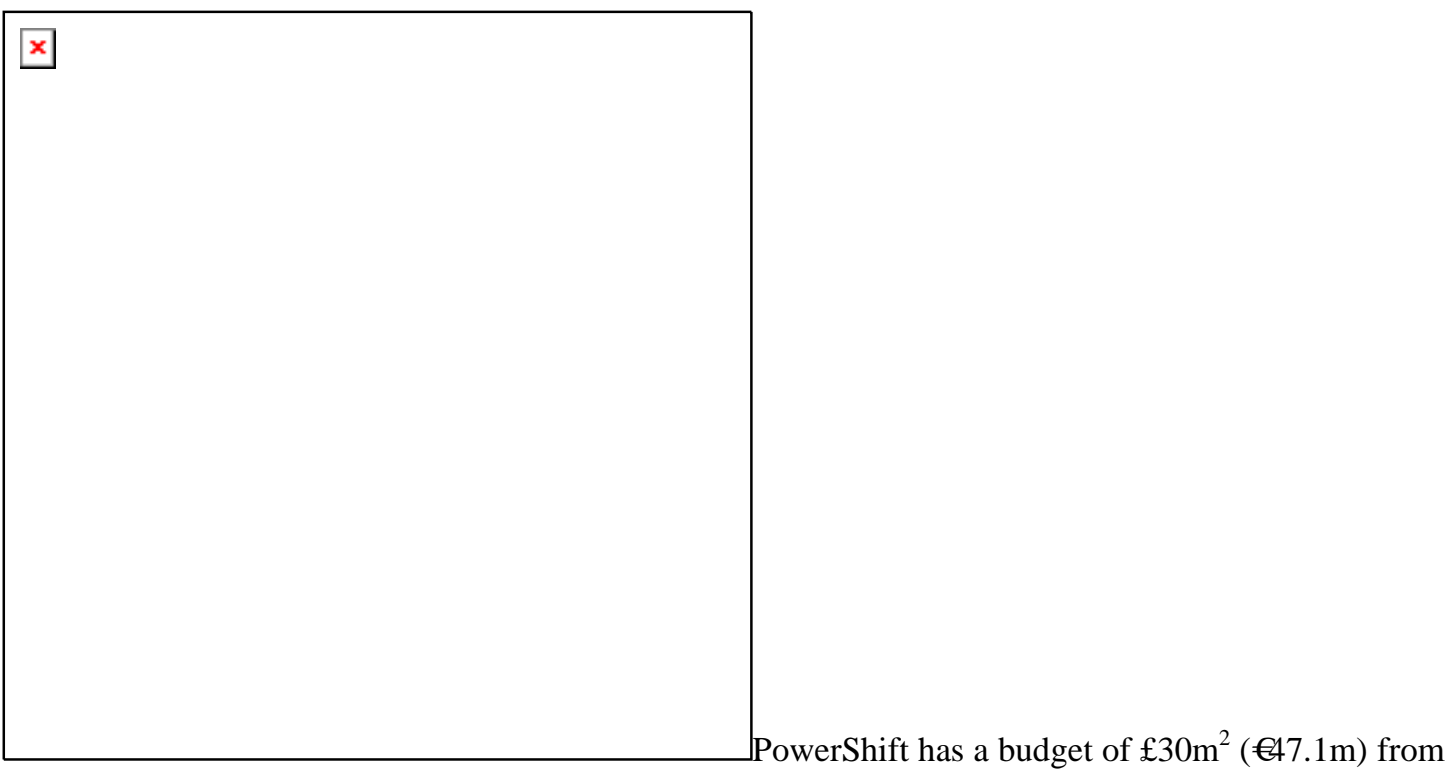

2001-4. Examples of Powershift-supported projects include fitting particulate traps to refuse trucks and converting buses to LPG.

The key assumption behind the Powershift programme is that a temporary subsidy programme can allow the market to mature to the point that the cleaner technologies can effectively compete. It is a good strategy to adopt to carve out an initial market presence. Hopefully once the marginal cleaner technologies get established (like particulate traps on diesels, and LPG/CNG engines), they can be left to their own devices and the subsidies concentrated on the next generation of cleaner technologies (e.g. hybrids) and then moved again to concentrate on things like fuel cell vehicles.

${ }^{2}$ Where $£ 1=€ 1.57(\mathrm{XE}, 2002)$ 
One question is whether the subsidy approach could work in a similar way for Travel Plans, in particular so that there would be a clear financial benefit for companies adopting them. There would also be a need for the subsidy instrument to get companies to realise internal financial benefits, meaning a link would need to be made - perhaps by making an audit of the company's travel costs a requirement of the grant. Simply bribing firms to introduce Travel Plans would not achieve this.

One possible way of achieving this, occurs in the State of Washington in the USA. Here, there are 30 cities that impose taxes, the money from which is then earmarked to pay for measures to cut peak hour congestion. For example, the employer tax charges $\$ U S 2^{3}$ (€2.14) per employee per month for 'high capacity transportation' projects or HOV lanes, commuter rail or vanpools. However, employers that participate in Travel Plan programmes are granted exemptions - i.e. they are effectively subsidised through the tax regime (Goldman et al, 2001). As the next section demonstrates, the fiscal regime is more usually used slightly differently.

\section{Fiscal System}

As already mentioned, in the USA Travel Plan policy is shifting from a regulatory approach to using tax incentives, and now tax incentives that were initially introduced to support regulation have replaced regulation at the Federal level. There has been much support for using economic instruments - the policy benefits of which were summarised in a report in 2000 by the Fabian Society's Commission on Taxation and Citizenship:

"In principle there are a number of advantages of taxes over other instruments. In particular, a tax is likely to be a more efficient method than a legal regulation. Unlike a legal regulation, which forces all firms to behave in exactly the same way, a tax allows them to choose their own response to the measure according to the costs of doing so. Firms which find it expensive to reduce the damaging activity will prefer to pay the tax, while those for whom reducing pollution is cheap will cut their damage further. This means that the goal is reached at the lowest total cost; that is, in the most efficient way. The uniform behaviour change of a legal regulation will generally have higher costs. A further advantage of taxes is that they encourage consumers continually to reduce their environmental impacts. Since every additional reduction will reduce the tax bill, there is always an incentive to cut further. Uniform standards by contrast provide no incentive to reduce damage beyond the standard set. This is a very important advantage, since one of the main motors of environmental improvement is innovation: improvements in technology and organisation which increase efficiency. Innovation almost always requires investment. This is likely to be encouraged where there are clear and ongoing financial benefits."

The Commission on Taxation and Citizenship (2000).

These sentiments also formed the concept behind the European Commission's green paper on Fair and Efficient Pricing for transport (CEC, 1995). The idea that taxation can be varied according to environmental impact has been used for a number of individual measures in a number of states. For example, in the UK less tax is paid on lead-free petrol and now ultra low sulphur petrol, while smaller-

\footnotetext{
${ }^{3}$ Where \$US1 = €1.07 (XE, 2002).
} 
engined vehicles and 'cleaner' vehicles pay a lower level of vehicle excise duty. Tax instruments can also be used to encourage commuting by 'greener' travel modes.

In relation to Travel Plans, the 1998 Integrated Transport White Paper the Government implicitly acknowledged that the present taxation regime fails to provide a positive incentive to the development of Green Transport Plans. The White Paper noted (para 4.131):

"An important issue is how employers and employees would respond to further changes in the tax system" (on employer-provided assistance to their staff's commuting) "and the relative impact of tax measures compared with other factors."

Important progress has been made to remove or reduce the various tax barriers to Travel Plan measures, in particular since the March 1999 Budget (Finance Act). This removed the inconsistency between National Insurance Contributions (NICs) and Income Tax rules (which actually makes more Travel Plan measures liable to NICs, but at least the treatment is now consistent). It also stated that no tax or NICs would be liable on:

- Works buses of 12 or more seats ${ }^{4}$ used mainly to bring employees to and from work;

- General subsidies to public bus services used substantially for commuting, provided that the employees pay the same fare as other members of the public ${ }^{5}$;

- Bicycles and cycling safety equipment.

- Workplace parking for bicycles and motorcycles.

- Alternative transport for car sharers to get home in exceptional circumstances, such as working late, domestic emergencies etc.

In addition, a cycling business mileage allowance of up to 7.5p (€0.12) per km was introduced, which was raised to 12.5p (€0.20) from April 2002. If employers do not pay this, employees can now claim the allowance themselves on their tax return.

The 2001 Budget contained a number of further reforms. For the business travel part of a Travel Plan, a new car passenger rate of 3p (€0.05) per km per passenger is to be introduced from April 2002 to encourage car-sharing on business trips. Also a minor exemptions clause was introduced covering up to six cyclists' breakfasts per year and the lunchtime use of a works bus.

The 2002 Budget provided a major new tax concession that stemmed from research conducted for the DTLR. (Potter et al 2001). For the first time, it is now possible to provide a tax-free subsidy for employees' bus fares. The 1999 tax exemption that allowed employers to support public bus services required employees to pay normal fares. This exemption has been extended so that there is no tax or NICs charge where employees are carried free or at a reduced fare.

\footnotetext{
${ }^{4}$ reduced to 9 or more seats from April 2002

${ }^{5}$ However, note this was extended from April 2002 permitting the subsidising of fares.
} 
It should be emphasised that this exemption is for local bus services only (not rail, tube, metro, tram or coach services). There also has to be a contract between the employer and bus operator. The last point is important. If an employer provides their staff cash or vouchers to buy bus tickets, that is still taxable; the employer need to have a contract with a bus operator to carry staff at reduced or free fares. However, there is total flexibility in how such contracts are drawn up, so this should be no real constraint to the Travel Planner. The contract could, for example, stipulate the use of vouchers.

The reason for restricting this exemption to local buses appears to be linked to the lack of capacity on the rail network, and a worry that a concession covering rail had the danger of throwing a lot of tax relief at long distance London commuters for no modal shift benefit. It would probably even worsen things by encouraging long distance commuting. Targeting buses provided good value for the tax losses involved. The DTLR study examined a wider 'travel voucher' concession that addressed these problems, but it looks like, that for the moment, the Government is taking a cautious approach.

However, these actions have largely removed tax disincentives to Travel Plans rather than provide a positive incentive for organisations to encourage their staff to alter their travel behaviour. As yet, the UK has not used its fiscal system to provide positive incentives to either individuals or commercial organisations to green travel. By contrast, in the USA ${ }^{6}$ since the mid-1980s the Federal Government has introduced a number of tax concessions specifically for company Travel Plans. The following section draws extensively on the Final Report to the Canadian National Climate Change Process in 1999 (IBI Group, 1999).

Policy in the USA reflects the research conclusion that "direct financial incentives or subsidies are a key element of successful programs” to reduce single car occupancy travel to work. This conclusion is based upon the monitoring of the effectiveness of various measures (Comsis Corporation, 1995; Litgermoet, 1998). A historical summary of Federal commuter benefits in the US is shown in Table 1.

\section{TABLE 1 Evolution of Federal Commuter Benefits in the United States (IBI Group, 1999)}

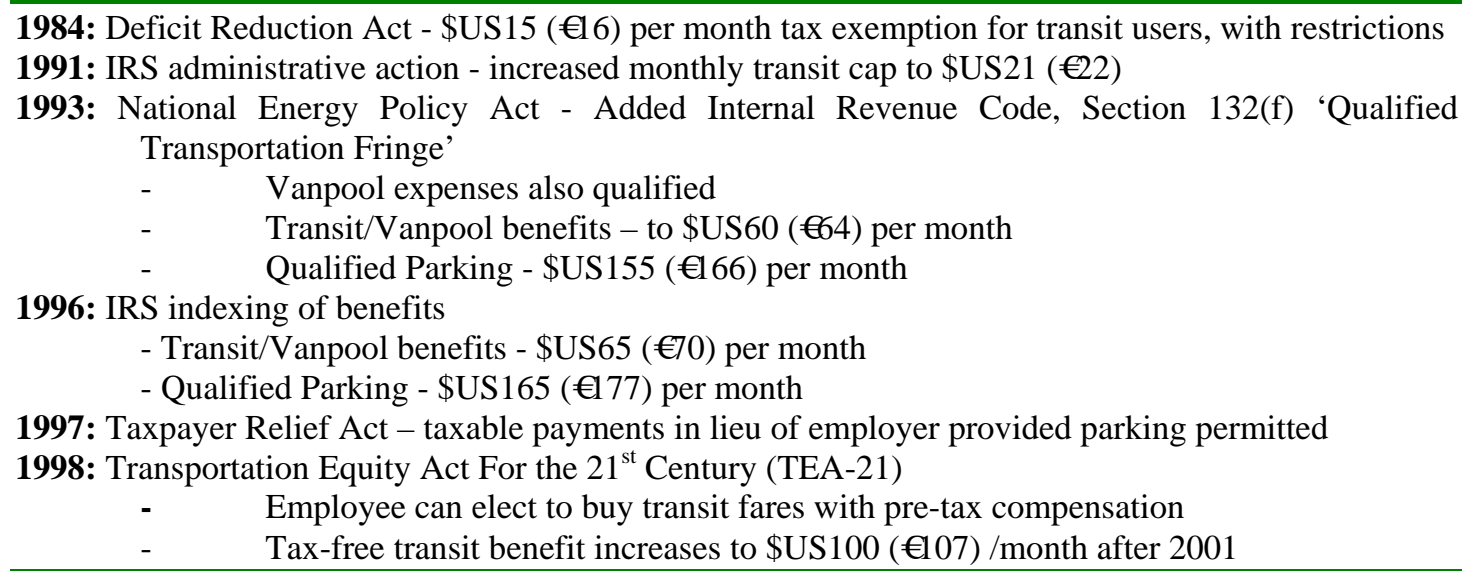

\footnotetext{
${ }^{6}$ It is important to note that in the USA, as in Britain, the taxation system the cost of travelling between home and work is not an allowable deduction for the purposes of assessing employees payroll tax.
} 
The provisions of the 1992 National Energy Policy Act forms part of the Internal Revenue Code. As of January 1993, an additional Section, 132(f) means employers can provide each employee commuting on transit a benefit up to an initial limit of \$US60 (€64) per month (\$US720 (€770) per year) which is tax deductible to the employer and tax free to the employee. The Energy Policy Act included adjusting the limits with inflation, rounded to multiples of \$US5 (€5).

The fact that employees and employers share the benefit is a key factor that has increased growth in the take up of the benefit from 2\% per month prior to 1998 to 10\% per month in 1999 (IBI Group, 1999). Employers do not have to contribute anything to the cost of their employees' public transport costs but employees still benefit; certain employers do limit their involvement in this way, whilst others make a (tax-free) contribution on behalf of their staff.

The Taxpayer Relief Act of 1997 and the 1998 Transportation Equity Act for the 21st Century have extended these measures to the cashing out of employer-provided parking up to the \$US65 (€70) a month ceiling. This Act also provided for increasing the nontaxable transit and vanpool benefit ceiling to \$US100 (€107) a month from January $1^{\text {st }}$ 2002, with the resumption of increases indexed to inflation. In addition, parking 'cash out' payments are now tax exempt. But it should be noted that qualified parking still attracts a tax benefit ceiling of up to \$US175 (€187) a month. These measures are all part of the shift in USA policy away from regulation towards the provision of tax incentives to encourage employer actions. In summary, the situation is now as in Table 2.

\section{TABLE 2 Summary of Tax Benefits for Employer TDM Measures in the United States (Adapted from Association of Commuter Transport, 1998)}

\begin{tabular}{|c|c|c|}
\hline $\begin{array}{l}\text { Alternative } \\
\text { Mode of } \\
\text { Transportation }\end{array}$ & Incentive & Tax Implications \\
\hline $\begin{array}{l}\text { Transit and } \\
\text { vanpools }\end{array}$ & 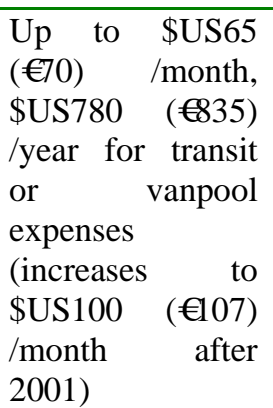 & $\begin{array}{l}\text { Employers give their employees up to \$US65 (€70) /month } \\
\text { to commute via transit or vanpools; get a tax deduction and } \\
\text { save over providing same value in gross income } \\
\text { Or } \\
\text { Employers allow employees to use pre-tax income to pay } \\
\text { for transit or vanpools and employers save on payroll tax (at } \\
\text { least } 7.65 \% \text { savings) } \\
\text { Or } \\
\text { A combination of both up to statutory limits }\end{array}$ \\
\hline $\begin{array}{l}\text { Qualified } \\
\text { Parking }\end{array}$ & $\begin{array}{l}\text { Up to \$US175 } \\
\text { (€187) /month, } \\
\$ U S 2,100 \\
\text { (€2247) /year, for } \\
\text { parking at or near } \\
\text { an employer's } \\
\text { worksite, or at a } \\
\text { facility from } \\
\text { which employee } \\
\text { commutes via } \\
\text { transit, vanpool, } \\
\text { or carpool }\end{array}$ & $\begin{array}{l}\text { Employers give their employees up to \$US175 (€187) } \\
\text { /month for qualified parking; get a tax deduction and save } \\
\text { over providing same value in gross income } \\
\text { Or } \\
\text { Employers allow employees to use pre-tax income to pay } \\
\text { for qualified parking and employers save on payroll tax (at } \\
\text { least } 7.65 \% \text { savings) } \\
\text { Or } \\
\text { A combination of both up to statutory limits }\end{array}$ \\
\hline
\end{tabular}

NOTE: Vanpool or Transit Benefits can be provided as well as Qualified Parking for total benefit of up to \$US240 (€257)/month or \$US2,880 (€3081)/year. 
These tax incentives have stimulated the development of new services to support their use. An example is the TransitChek scheme, used in New York and elsewhere in the USA. Employers purchase \$US15 (€16) and \$US30 (€32) vouchers from the New York TransitCenter, an alliance of transit operators that administers the program for the tri-state region. The vouchers can then be distributed to employees (Paaswell, 1994).

Tax is also an instrument at a local level in the USA. Businesses in the State of Oregon for example, can receive a $35 \%$ tax credit for their investments in trip-reduction activities, including telework equipment for their employees, vans for vanpooling, bus passes, and more (Litman, 2001).

Unlike in the UK and the USA, in many European countries commuting has always been tax deductible. In several of these countries (e.g. Norway, Germany, Belgium, Switzerland) there have been moves (some significant) to increase general benefits for more sustainable modes relative to less sustainable methods of travel. But, the use of such general concessions appears to have stimulated car commuting and trip lengthening, and reducing benefits to car commuters is politically very difficult. In many cases the environmental and transport impacts are entirely negative. Perhaps the main exception is in the Netherlands, where changes to the treatment of transport tax benefits have been linked to wider taxation reform.

This occurred only after the approach of making incremental and detailed changes in the tax rules was abandoned - mainly because the system became far too complex as to be unworkable. Therefore, from $1^{\text {st }}$ January 2001 the commuting benefits system was radically overhauled, partly to simplify it, and partly to further promote the use of alternative modes. While this process resulted in car users collectively being financially worse off, the change to the system of commuting benefits is part of a wider reform to the tax system where personal tax allowances have been increased. This cost the Treasury some $€ 2.7 \mathrm{bn}$ per year, but it is equitable, since all employees will enjoy it regardless of mode, and it has no direct influence on choice of mode of transport for the trip to work.

Overall, the taxation system in the Netherlands now favours 'greener' modes of travel, so Travel Plan measures introduced by employers are exempt from negative tax impacts, or are actually enhanced. Following an initial round of incremental tax reforms, the Dutch government realised that, rather than adding on transport and environmental considerations to adapt existing tax measures, they needed to be a core criteria in a major reform of the whole tax system itself. This evolution in tax policy should be noted. By linking transport tax 'sticks' to both transport tax and general tax 'carrots', they have achieved a radical reform that has eluded most other countries.

\section{Conclusions}

Travel Plans in the UK are basically a policy implemented using information and exhortation, which has been supported by redirecting existing planning gain regulation and providing some low cost tax reforms. Although some of the tax disincentives to Travel Plans have been removed, the fiscal system still does not provide any real benefit to employers to take Travel Plans seriously. Equally when planning consent is needed employers will comply with a Travel Plan, at least for a year or two. 
Overall, neither regulation nor tax measures have been used to their full potential. It is all very patchy. The end result is that while Travel Plans clearly can deliver results, they are not being implemented to their full potential. There is neither sufficiently consistent, targeted regulation nor sufficiently consistent, targeted fiscal measures that will result in anything like the widespread adoption of Travel Plans.

What is more, this half-hearted approach to Travel Plans sends contradictory signals. Where it hits, planning consent regulation does get Travel Plans onto employer agendas, but in these situations it is very much seen as a cost and not as something that employers should do as a normal business practice. Meanwhile information measures are constantly pushing the cost-effectiveness message, but to little effect. At the same time huge subsidies have been used to encourage companies to buy clean vehicles, which are often being promoted alongside Travel Plans with the implication that if you have cleaner vehicles there is no real need for modal shift. By contrast no subsidies (besides small amounts for advice) are offered for Travel Plan development. As a result, the greener vehicle tax incentives and benefits are now becoming part of company culture, whereas as soon as the planning consent pressure is off, Travel Plans wither away.

The lessons from abroad are clear. If the policy is to work, then appropriate instruments are necessary to ensure that the policy objectives are achieved. In the USA the Travel Plan policy was initially regulation-led with tax concessions playing a supporting role, whereas now the balance has been reversed. This has meant that whole private industries are springing up to support and promote tax efficient Travel Plan benefits. The Dutch approach has been a more even-handed mix of planning regulation and tax incentives.

Overall, transport will never be the core concern of the vast majority of employers, and so the current informational instruments-dominated policy is unlikely to very effective unless it is supported by additional measures. The need to use regulation and fiscal measures seems so blatantly necessary, but has not as yet been understood in the UK. The issue of whether regulation, tax or a subsidy policy works best is a secondary issue to that of needing it in the first place.

The juxtaposition of an ambitious policy for Travel Plan uptake and the use of insufficiently effective instruments is perhaps a microcosm of transport policy in Britain as a whole. The need, in terms of the cost of congestion, transport casualties, climate change emissions and backlog of under investment is obvious. Yet transport policy is such a politically difficult area that government balks at using the fiscal and regulatory measures that will deliver results and instead talks up minor and ineffective measures as though they will actually deliver significant improvements.

Perhaps Travel Plans are a litmus paper for British transport policy, and when real incentives to the commercial sector to deliver Travel Plans appear then there may be hope for transport policy as a whole. 


\section{Acknowledgements}

This paper is partially based on research work conducted for the Department of the Environment, Transport and the Regions (now the DTLR), and the Inland Revenue.

\section{References}

Association for Commuter Transportation (1998) Money Saving Tools, Explanation of the Federal Tax Advantages for Employer-Provided Transportation Benefits, from the TDM Tool Kit.

Commission of the European Communities (1995) Towards Fair and Efficient Pricing in Transport. Policy options for internalising the external costs of transport in the European Union. Green paper. CEC, COM (95) 691, Brussels.

Commission of the European Communities (1998) Fair Payment for Infrastructure Use, White Paper, CEC, COM (98) 466, Brussels.

Comsis Corporation (1993) Implementing Effective Travel Demand Management Measures: Inventory of Measures and Synthesis of Experience, USDOT and Institute of Transportation Engineers (www.ite.org).

Comsis Corporation (1994) A Guidance Manual for Implementing Effective Employer-based Travel Demand Management Programs, FHWA and FTA (www.bts.gov/ntl/DOCS/474.html).

Coulliard L (2002) Mobility management in the Montréal region: partnership strategies and transportation management areas, The Economic Community Workshop, Proceedings for the European Conference on Mobility Management, 15-17 May, Ghent.

Department of the Environment, Transport and the Regions (1998) The Benefits of Green Transport Plans, DETR, The Stationery Office, London.

European Council of Ministers of Transport (1997) Internalising the Social Costs of Transport, OECD, Paris.

Flowerdew, A.D.J. (1993) Urban traffic congestion in Europe: Road pricing and public transport finance. Economist Intelligence Unit, London and New York.

Gailly J P (2002) Travel Plans and the Belgian Experience, Plenary Session, Proceedings for the European Conference on Mobility Management, 15-17 May, Ghent.

Goldman T, Corbett S and Wachs M (2001) Local Option Transportation Taxes in the United States, Institute of Transportation Studies, University of California at Berkeley, Research Report UCB-ITSRR-2001-3, March.

HM Treasury (2001) Budget Report 2001, HM Treasury, The Stationery Office, London, March.

IBI Group (1999) Tax Exempt Status for Employer Provided Transit Benefits, Final Report to the Canadian National Climate Change Process, Transportation Issue Table, chaired by Transport Canada, Ottawa, June. 
Institution of Highways and Transportation (1997) Transport in the Urban Environment, IHT, London.

King County Metro (1999) Flexpass, King County Metro, 12 April, http://transit.metrokc.gov. Accessed 15 August 2001.

King County Metro (2000) Pass Subsidy Programs, King County Metro, 10 January, http://transit.metrokc.gov. Accessed 15 August 2001.

Ligtermoet M. (1998) Mobility Management in the Netherlands, Report to the Netherlands Ministry of Transport, Netherlands Ministry of Transport.

Litman T. (1997) Employer Provided Transit Passes: a Tax Exempt Benefit, Victoria Transport Policy Institute, British Columbia, Canada.

Litman T (2001) Commute Trip Reduction (CTR): Programs That Encourage Employees to Use Efficient Commute Options, TDM Encyclopedia, Victoria Transport Policy Institute, March. http://www.vtpi.org. Accessed 15 August 2001.

Modarres A, (1993) Evaluating Employer-Based Transportation Demand Management Programs, Transportation Research Record A, Vol. 27, No. 4, pp. 291-297.

MOST (2001) A ride around Rome: Implementation of the Italian MM Decree, Mobility Centres and Mobility Consulting, MOST News, No.3, December.

OC Transpo (2001) OC Transpo's Transit Pass Payroll Deduction Program, http://www.octranspo.com. Accessed 15 August 2001.

Paaswell R. E. (1994) Employee Commute Options Guidebook, Transportation Demand Strategies Technical Memorandum \#7, University Transportation Research Center, New York, May.

Potter S., M. P. Enoch, T. Rye, and C. S. Black (2001) The Potential for Further Changes to the Personal Taxation Regime to Encourage Modal Shift, Final Report to the Department of the Environment, Transport and the Regions and the Inland Revenue, The Open University, Milton Keynes, June. Visit http://www.dtlr.gov.uk/itwp/modalshift/index.htm. Accessed 17 March 2002.

Rye T (1999) Employer Attitudes to Employer Transport Plans: A Comparison of UK and Dutch Experience, Transport Policy, Vol.6, pp.183-196.

Rye T (2002) Travel Plans: Do they work?, Transport Policy, forthcoming.

Santos-Pereira A L and Alouche P (1999) The funding of metro extensions in Sao Paulo, Urban Public Transport Funding, UITP Seminar, Paris, 13-14 October.

Schippani R (2002) Mobility consulting for companies through the City of Linz, Economic Community Workshop, Proceedings for the European Conference on Mobility Management, 15-17 May, Ghent.

Shreffler, E. N. (1999) What Makes for Successful TDM Programs?, Louisville-Southern Indiana Ohio River Bridges Project, October, http://www.kyinbridges.com/researchofdemand.htm. Accessed Jul. 31 2001. 
Transit Center, (undated) New Federal Commute Benefits With The TransitChek Program, a presentation by the Transit Center.

Transit Co-operative Research Program (1996) Transit and Urban Form, Volume 2, PART IV Public Policy and Transit-Oriented Development: Six International Case Studies, TCRP Report 16, Transportation Research Board, National Research Council, The Federal Transit Administration, Washington DC.

US Evironmental Protectection Agency (2000), Examples of Commuter Choice Programs: Santa Monica Parking Cash Out, Office of Transportation and Air Quality, US EPA, 11 May. http://www.epa.gov/oms/transp/comchoic/waytogo.htm. Accessed 15 August 2001.

US Government (1992), National Energy Policy Act, Section 1911.

Van den Branden, T., S. Potter, M. P. Enoch, and B. J. Ubbels (2000) Fair And Efficient Pricing In Transport - The Role Of Charges And Taxes. Report for European Commission DG TREN, Oscar Faber, Birmingham, England.

Van der Hallen P (1999) Employers oppose compulsory commuting plans, Steunpunt WAV, Brussels, Belgium, 28 March. European Industrial Relations Observatory On-Line, European Foundation for the Improvement of Living and Working Conditions. Visit http://217.141.24.196/about/1999/03/feature/BE9903264F.html. Last accessed 31 May 2002.

Washington State Department of Transportation (1999) Employee Transportation Co-ordinator Handbook, Washington State CTR Program (www.wsdot.wa.gov/pubtran/ctr).

Winters P and Rudge D (1995) Commute Alternatives Educational Outreach, National Urban Transit Institute, Center for Urban Transportation Research, University of South Florida (Tampa; www.cutr.eng.usf.edu).

XE (2002) Currency Converter, XE.com. Visit http://www.xe.com. Last accessed 31 May 2002. 